\title{
IMPLEMENTATION OF INDONESIA'S MARINE POLICY A CASE STUDY: \\ (Implementation of Presidential Regulation No. 16 of 2017 Concerning Indonesian Maritime Policy, Specifically Maritime Diplomacy in Papua)
}

\author{
Mahmud Ridho Ardi ${ }^{1}$; Agus Subianto²; Sudirman ${ }^{3}$ \\ ${ }^{1}$ Students of Public Administration Magister Program of Hang Tuah University \\ 2,3Lecturers of Public Administration Magister Program of Hang Tuah University \\ Corresponding email: moropalapa19147@gmail.com
}

\begin{abstract}
Good management of international relations has been a major concern of Indonesia's foreign policy since the country's independence. The character of the nation and state leaders is often the determining factor that causes relations between countries in a situation full of uncertainty. Some parties, based on the analysis of confidential documents, are allegedly trying to influence the policies of their respective countries to give recognition to Papuan independence and sovereignty. Based on Presidential Regulation No. 16 of 2017 concerning the Indonesian Maritime Policy dated February 20 , 2017, Indonesia's geographical and demographic conditions will have consequences for the emergence of the real challenges for Indonesia that must be managed comprehensively. Specifically, in Papua, referring to data from the Navy of 2019, at least in the last period more than 50 (fifty) transnational crime and intrastate conflicts (communal conflicts and separatist movements) occurred in Papua. In addition to maritime defense forces, maritime diplomacy as a form of state policy has been transformed into an alternative in efforts to reduce the vulnerabilities that have arisen in the Papua region. The Navy as a military force is part of implementing the policy to realize the main program of Maritime Diplomacy, namely increasing the active role in efforts to create world peace and security. The Indonesian Navy describes the policy through the perspective of modern maritime defense policies that understand the nation's history to meet the political will aspects (maritime diplomacy) through cooperative, persuasive and coercive efforts. There are six factors that influence the implementation of the Maritime Diplomacy Policy in Papua, including: 1) Size and Policy Objectives;2) Resources; 3) Characteristics of Implementing Agencies; 4) Communication between Implementing Agencies and Implementing Activities; 5) Disposition of Implementing Agencies; and 6) Environmental Effects. Environmental influences are the most influencing factors in implementing policies. The influence can come from inside or outside. The main internal influence comes from the longstanding conflict in Papua. External influences take the form of conventional and non-conventional threats.
\end{abstract}

Keywords: Maritime, Diplomacy, Papua

\section{INTRODUCTION}

Good management of international relations has been a major concern of Indonesia's foreign policy since the country's independence. A minimalist approach to dealing with bipolarity was applied by Indonesia during the Cold War. This is certainly in line with Indonesia's foreign policy, that is, "free and active" arising from the existential notion of vulnerability and distrust of great powers (delivered by Muhammad Natsir, Indonesian Foreign Minister in 1948). At present, Indonesia faces multi-polarity by using an optimality approach that aims to give Indonesia a sense of independence and balance in relation to the main forces that exist today.

International relations between countries where there is an interest behind it has become a trend of the current phenomenon. The character of the nation and state leaders is often the determining factor that causes relations between countries in a situation full of uncertainty. In the regional region, Asia Pacific, the leadership characteristic of the President of the United States of America (US) Donald Trump has succeeded in increasing the escalation of diplomatic relations between countries. His controversial statements and decisions can turn a safe situation into a real conflict that impacts other countries. In addition to the policy of increasing import duties, Trump's actions in signing the Hong Kong Human Rights Act in $\mathbf{2 0 1 9}$ have made the situation in the Asia Pacific region heat up because the US has managed to corner China in its internal conflict with Hong Kong residents.

The active role of the US in the Asia Pacific region has led to various speculations 
about the stability of regional security. After the Cold War, US security policy focused a lot in the Middle East region and seemed to 'forget' the Asia Pacific region. The emergence of China with its economic and military power in recent decades has made the US aware of the meaning of geopolitics and geo-strategy in the Asia Pacific Region that is so large today (Leon Panetta, US Secretary of Defense of the 2012 Asia Pacific military leadership meeting).

Panetta stated that the US plans to shift $60 \%$ of its combat fleet in the Asia Pacific from 2012 to 2020, such as Diego Garcia, Christmas Island, Coco Island, Darwin, Guam, Subic, to Malaysia, Singapore, Vietnam and also to the Andaman Islands, Nicobar Islands, and others. US Navy aircraft carriers will be stationed in Singapore. The US, according to Panetta, is also trying to return to military bases in the Philippines and try to open another new base in the Asia Pacific region.

In November 2011 US President Barack Obama announced an increase in military cooperation with Australia which was implemented through the presence of American troops in Australia. The US withdrew some of its troops in the Arabian Peninsula to be stationed in Australia; this action became known as Darwin rotation forces. In April 2012 the US realized its policy by placing 2,500 trained personnel in Darwin Australia (Berlianto on international.sindonews.com, 2018).

US President Barack Obama during his visit to several Asian countries in April 2014 stated his commitment to balance policies to attract military forces and US political, economic resources currently in the Middle East to then be placed in the Asia Pacific (Kevin Liptak on cnn.com, 2014). This US policy has had the effect of changing the map of military power in the Asia Pacific region and the world. The presence of US troops in Darwin, according to Liptak, will affect the security situation of regional countries. If faced with Papua which is about 820 KM from Papua which is the sovereign territory of Indonesia, the presence of these troops should be taken into account. The presence of these troops is suspected to be a standby force to maintain the stability of Freeport's security which is the largest US asset in Indonesia that has been fully controlled by the US since 1967.

Papua's armed separatist activities have experienced a significant escalation increase since 2012. OPM has been proven to be supported by foreign intelligence under the guise of NGOs, businessmen, missionaries and tourists in Papua (Human Rights Watch at hrw.org, 2011). Conflicts that occur in Papua, according to the text above, it is possible to use the Hybrid Warfare military strategy by implementing political warfare combined with conventional warfare, irregular warfare and cyber warfare. This is very possible because of the alleged involvement of foreign parties. This was clarified based on information on a leaked 500-page Kopasus confidential document. Some of the names listed in the document helped drag the big men in the international world such as former United States Senator Edward Kennedy, Russ Feingold, Patrick Leahy and Dianne Feinsten. Also named were Bishop Desmond Tutu (South Africa), Bob Brown (Parliamentary Leader of Australian Greens), Lord Avebury and Jeremy Corbyn (member of the British Parliament) and former Prime Minister of Papua New Guinea Sir Michael Somare.

The individual, based on an analysis of Kopassus confidential documents, is allegedly trying to influence the policies of each country to provide recognition of Papuan independence and sovereignty. The Indonesian government, with the strength of its diplomacy, is demanded to block the entry of foreign influences (individually) who want to involve their country in the effort to recognize sovereignty against the Papuan separatist movement.

Papua in fact, according to history, has a very high strategic value for Indonesia's geopolitics due to geographical factors and the availability of natural resources contained therein. Papua's strategic position bordering countries with potential economic strengths ranging from the Philippines to the north, Hong Kong, Taiwan, Japan, to the Pacific islands and the Americas on the east and south facing Timor Leste and Australia has posed threats to Indonesian territorial sovereignty.

Based on Presidential Regulation No. 16 of 2017 concerning Indonesian Marine Policy dated February 20, 2017, Indonesia's geographical and demographic conditions will have consequences for the emergence of various real challenges for Indonesia that must be managed comprehensively. Specifically, in Papua, referring to data from the Navy of 2019, at least in the last period more than 50 (fifty) transnational crime and intrastate conflicts (communal conflicts and separatist movements) occurred in Papua. This is fertile ground for illegal activities, especially arms smuggling. This was confirmed by Papua Regional Police Chief Inspector General Paulus Waterpauw in his press release dated January 25, 2019, namely "ammunition and gun owned by KKB partly smuggled from abroad, and partly obtained from within the country".

The separatist movement in Papua, according to history, has proven that smuggling of illegal weapons by sea originating from abroad, especially from the Philippines, brings double benefits for them. On the one hand, their armed forces increased; on the other hand it indirectly proved that there was a power from outside the state that supported their movement. This is a challenge for the Government in maintaining the maritime sovereignty, both using soft and hard power. 
To maintain its maritime sovereignty, the Indonesian government needs strong control over the security, integrity and sovereignty of the territory of the Republic of Indonesia. This includes protecting key areas such as, Papua, the easternmost region with vast territorial waters (Indonesian Foreign Minister, Retno L. M., 2014).

President Joko Widodo has issued Presidential Regulation No. 2 of 2015 concerning the 2015-2019 RPJMN in which the World Maritime Axis concept is enshrined in which the maritime sovereignty of Indonesia is maintained. This policy is supported by five main pillars. Efforts to uphold sovereignty and maintain the integrity of the Unitary Republic of Indonesia in Papua can be supported by the main pillars of the concept, in particular, the implementation of maritime diplomacy and maritime defense forces. The successful implementation of the policy will provide a sense of security and comfort for both the people of Indonesia, especially those living in the Papua region.

Feeling comfortable and safe to live and go to sea in the territorial waters of Papua, based on a study of the analysis of Papua by the Indonesian Navy, will encourage the community to work together with the authorities to defend the sea area from foreign parties who carry out illegal activities. Maritime sovereignty through the deployment of Navy ships and TNI Air Force aircraft is needed to have a daunting effect on the possibility of infiltration of foreign ships/aircraft bound for Papua.

In addition to maritime defense forces, maritime diplomacy as a form of state policy has been transformed into an alternative in efforts to reduce the vulnerabilities that have arisen in the Papua region. Related to this, the Navy needs to actively support maritime diplomacy in accordance with the Trinity theory put forward by Ken Booth (Navies and Foreign Policy, 1979), that basically all Navy throughout the world has three roles namely military, policy action, diplomacy.

The research that will be carried out has similarities to the research conducted by Nugraha and Sudirman (2016) is research on maritime diplomacy, while in the research of Peni Susetyorini (2019) both study Indonesia's marine policy. Meanwhile, the similarity with the research of Syarifudin Tippe (2013) is to study the implementation of a policy with the Papua locus which has special characteristics in the life of the state in the Republic of Indonesia. The research equation that will be carried out with previous research is both using a qualitative approach. In this study the sharpness of logical analysis is prioritized to clearly describe the discussion of the problem. The difference with previous research is that this research focuses on the implementation of maritime diplomacy policies faced with vulnerability in Papua from the maritime aspect.

\section{MATERIAL AND METHODS}

\section{Participants/Subject/Population and Sample}

This research uses qualitative method with an intrinsic case study approach that focuses on the case itself, because it is considered unique or unusual. A holistic analysis will be carried out to continue purposeful sampling (selection of cases that are considered important) through detailed descriptions of the patterns, context and settings in which these cases occur.

This research was conducted to find out the results of the implementation of maritime diplomacy policy in Papua and the influencing factors as consideration for formulating new policies that are more adaptive, in this regard the researchers used primary data sources (Navy Headquarters; Commander of KAL Wayag; and Communities living in Papua) and secondary data sources (other data, which is contained in books or other documents that are indirectly related to the problem under investigation).

\section{Instruments}

Data collection techniques are the most important step in research, because the main purpose of research is to get data. In qualitative research, data collection is done in natural settings, primary data sources and data collection techniques are more on participant observation, in-depth interviews and documentation (Sugiyono, 2014). In this study the instruments used by researchers were equipped with interview guides which were used as guidelines for conducting interviews with informants. While the tools and materials used to support are tape recorders, cameras and other stationery.

\section{Data Analysis Procedures}

Data were analyzed using several steps according to Miles, Huberman and Saldana (2014) theories, namely analyzing data in three steps: data condensation, data display, and drawing conclusions or verification (conclusion drawing and verification). Data condensation refers to the process of selecting, focusing, simplifying, abstracting, and transforming.

\section{RESULT \& DISCUSSION}

General description of the research location and the history of the relationship between Tanah Papua and the outside world illustrates that Presidential Regulation No. 16 of 2017 on Indonesian Maritime Policy dated February 20, 2017 related to maritime diplomacy, especially in Tanah Papua, will face an unusual level of difficulty if implemented in other regions in Indonesia. Indonesia. Thete are several factors found by researchers to have an influence on the implementation of the policy as follow:

\section{Size and Policy}

Based on Presidential Regulation No. 16 of 2017 stated in concerning Indonesian Maritime Policy 
dated February 20,2017, to realize the vision of Indonesian Maritime Affairs, it is necessary to set targets as a mission of Indonesian Maritime Policy. In this case, maritime diplomacy is the 11th (eleven) target of 12 (twelve) targets that have been set. It was also explained in the attachment of the Presidential Regulation that maritime diplomacy was the implementation of foreign policy aimed at optimizing the potential of the sea to meet national interests in accordance with national provisions and international law.

Attachment of Presidential Regulation, page 57 (fifty seven) paragraph 2 (two) states that Indonesian maritime diplomacy cannot be interpreted narrowly in the form of international negotiations in the field of maritime affairs, border determination or naval diplomacy. Indonesia's maritime diplomacy is the implementation of foreign policy which is not only related to various marine aspects at the bilateral, regional and global levels but also which uses marine assets, both civilian and military, to fulfill Indonesia's national interests in accordance with the provisions of national law and international law.

The involvement of the Indonesian Navy is straightforwardly spelled out in the 2 (two) programs of the 7 (seven) main programs of maritime diplomacy policy strategies written in the attachment to the Presidential Regulation. This is in line with the theory of neorealism where through military involvement a balance of power is achieved to achieve peace. The Indonesian government, in accordance with Waltz's thoughts, will achieve its interests (maritime diplomacy) with power in the form of the military.

The implementation of maritime diplomacy policy in the Land of Papua is not much different from the direction of Indonesia's Maritime policy and the contents of the Blue print above. The document aims to provide guidance in an effort to increase military cooperation in order to accommodate national interests externally to create a safe and peaceful regional region. This was carried out through international cooperation in the areas of operations and training, coordinated patrols, Passing exercises and Port Visit.

The Indonesian Navy also describes the policy through the perspective of modern maritime defense policies by understanding the history of the nation to meet aspects of political will (maritime diplomacy). Navy analyst staff in observations conducted by researchers said that the concept of Defense has experienced a proliferation of maritime dimensions by experiencing an expansion of meaning not only to the concept of sea defense against military threats from other countries, but also included in defense against non-military threats. Defense against nonmilitary threats, simply, protects the purpose of maritime diplomacy to optimize maritime potential through efforts to eradicate illegal actions at sea, such as armed piracy, piracy, people / goods smuggling, illegal drugs, illegal fishing, terrorism, and separatism that occur in Papua. become a national security issue. Neorealism theory says that national security is the main issue and occupies the top place of other issues. Related to this the state essentially becomes a rational actor to overcome them.

The Indonesian Navy, as part of a rational actor, has conducted operations throughout the year to secure Papua's territorial waters. Navy AL staff analyst said that the operation was carried out based on intelligence considerations based on the social and cultural conditions of Papua in the Papua region. This was done also as a form of persuasive maritime diplomacy of the Indonesian Navy, "showing the flag", to show existence to foreign countries. The Indonesian Navy's current aim is to become a maritime force capable of supporting Maritime Diplomacy Policy, especially in the Land of Papua.

\section{Resources}

"The implementation of Maritime Diplomacy Policy in the Land of Papua is very dependent on the human resources involved", this was stated by staff from the Navy Headquarters during interviews with researchers. Professional human resources are believed to be a supporting factor in the successful implementation of this policy. The amount of military budget allocation specifically for the Papua region cannot be known because it is confidential. However, the Navy analyst staff expressed his opinion that the budget conditions were not yet in an ideal condition to cover all activities in the Papua region in order to support maritime diplomacy policies to run optimally.

KAL Wayag commander who operates in the Papua region, Captain Laut $(P)$ Erwin Teguh, in an interview session said "KAL I have limited endurance and range, it is impossible to cover the entire Papua region". From this information it can be seen that the facilities and infrastructure are still not ideal for maintaining the sovereign territory of the Republic of Indonesia in Papua in the context of implementing the Maritime Diplomacy Policy.

The Indonesian Navy with its limitations has sought to budget for the activities of the Port Visit and Foreign Scholars in its annual activities. During the event a cocktail party was held, in which the Navy personnel involved performed a hunting dance from Papua among several other performances. This is a cooperative maritime diplomacy undertaken by the Navy for Papua in the international world.

The activities carried out by the Indonesian Navy in the context of implementing the Maritime Diplomacy Policy in Papua are active in the international organizations $\mathrm{IMO}$ and $\mathrm{IHO}$. This involvement is in line with the concept of neorealism in which the state is seen as a unit of actors, wherein the Indonesian Navy completes 
the Ministry of Foreign Affairs in an effort to engage in diplomacy with other countries. The diplomacy carried out, in addition to requiring a large budget, also requires a short amount of time in completing several rules relating to border, security and safety, especially in the Papua region.

Mr. Ottis in an interview session said that "Papua's Maritime Diplomacy policy takes a long time to be said to be successful", it is realistically faced with the existing limitations. However, according to him, this is not an impossible thing, depending on the willingness and consistency of the implementers of the policy, "if there is an intention and a clean heart, it will definitely succeed".

\section{Characteristics of Implementing Agencies}

Papua is a vast territory with a land area almost half of the total area of the island of Papua. Papua's territorial waters are also vast with natural resources contained making the region a foreign country. The implementation of Maritime Diplomacy Policy as conveyed by the theory of neorealism cannot be carried out by state actors alone, it requires non-state actors as an integrated unit. The Indonesian Navy cannot be a single agency to implement Maritime Diplomacy policies in the Papua region. Other maritime stakeholders such as KKP, Bakamla and Customs and Excise are needed to work together to implement Maritime Diplomacy Policy with standard operating procedures (SOP) and their respective responsibilities. The implementation of this synergy was verified by the statement of $\mathrm{KAL}$ Wayag Commander, "in the field I often encounter elements from other law enforcement agencies actively carrying out patrols in the Papua region".

The Navy, as a formal government agency, is the main actor in its implementation in accordance with the theory of neorealism. However, according to the other basic principles of neorealism theory, the involvement of nonformal organizations in the effort to implement policies is also wide open. In his interview Mr. Ottis said that "Papuans want to help the government, just leave it with the opportunity or not. We in Papua and outside Papua are ready to support Government policy ". The training and support of fishing facilities and infrastructure for Papuans is a clear example of this engagement. This will dismiss the fact that Papua's territorial waters are used by fishermen from Pantura or from abroad. This action is expected to be able to change the agrarian vision of the Papuan population to become a maritime.

The problem arises in the process of policy fragmentation in which interest groups, especially from business circles, intervene more in maritime diplomacy policies in Papua. In addition to the presence of fishermen from outside Papua, in 2017, the Navy recorded there were about 7 (seven) tourism areas in the Raja Ampat Islands managed by foreign parties. Efforts to advance maritime potential through foreign investment schemes have become a dilemma for the government amid threats to the integrity of the Unitary Republic of Indonesia from the Papua conflict.

\section{Communication between Implementing Agencies and Implementing Activities}

Communication will never be separated from telecommunications facilities. Facilities and supporting infrastructure that are not good will be a barrier to the smooth communication process and the implementation activities. In the era of technology 4.0, the availability of the internet becomes a benchmark of the smooth communication. The Papua region is the least touched area of internet facilities in the territory of Indonesia.

$\mathrm{Mr}$ Ottis in his statement said that "there must be obstacles, communication facilities for example, in Papua not all regions have good communication networks. But I am sure the Government has a way to overcome it ". This shows the public's trust in the Government's commitment to carry out human and infrastructure development in Tanah Papua. The implementation of maritime diplomacy policies carried out by the Indonesian Navy in the Papua region, according to information from the staff of the Indonesian Navy headquarters, was carried out in a single unit. Tiered information is conveyed well, from the leadership to the implementers in the field. The policy of the Navy's leadership in the field of Maritime Diplomacy to implementers in the field is overseen by the Commander in Chief of the Armed Forces III domiciled in Sorong, West Papua. Communication constraints from broadband and mobile operators can be overcome through radio communication from base to base or to the $\mathrm{KRI}$ that is operating.

The manifestation of the synergy between stakeholders in the effort to implement the Maritime Diplomacy policy is contained in the implementation of the proposed change of name of the island and the strait carried out jointly between the Navy, the Ministry of Foreign Affairs and several other relevant stakeholders. The Dampier Strait which was previously the name given by British sailors to the area separating the Raja Ampat islands and the mainland of the island of Papua is in the process of submitting a change of name. The success of this name change will later become a form of synergy and the success of maritime diplomacy in Papua.

\section{Disposition of Implementing Agencies}

In drafting a policy, it is fitting to go through several test phases, one of which is an analysis of the environment. The involvement of implementing agencies in the policy formulation process has been carried out, this was stated by the Navy staff during the interview. The Ministry of 
Maritime Affairs has conducted several coordination meetings involving maritime stakeholders before this Policy was established. Togetherness in the process of formulating policies produces a unified understanding of almost all implementing agents in the field, including the Navy. This was stated by the Navy staff during the interview. This policy at the lower level can be well received because of the Oath of Warriors who are guided by all members of the TNI who are active as implementers in the field.

\section{Environmental Effects}

Maritime diplomacy carried out in Tanah Papua covers Papua and West Papua Provinces administratively. The implementation of maritime diplomacy is inseparable from environmental factors, especially social and political that occur both from within and from abroad. The main environmental influences from the prolonged conflict in the Land of Papua. The Navy staff stated in the interview that there was a shift in the pattern of vulnerability in Papua from the Act of Free Choice to the present.

The Navy staff in conducting the observation stated that the source of the Papua conflict included the following four strategic issues: the history of Papuan integration into the Unitary Republic of Indonesia and the political identity of the Papuan people; political violence and human rights violations; the failure of development in Papua; and government inconsistencies in the implementation of Otsus and the marginalization of indigenous Papuans. Historically, interpretations of the history of integration, political status, and political identity of Papua emerged as a result of the political struggle for power during Papua's decolonization. Whereas political violence and development failure are the implications of the New Order authoritarian regime. Meanwhile, government inconsistencies in the implementation of Otsus are more a problem that emerged in the post-New Order era.

\section{CONCLUSION}

Implementation of Presidential Regulation No. 16 of 2017 concerning Indonesian Maritime Policy, specifically Maritime Diplomacy in Papua has been implemented by implementing agents in the field (in this case the Navy) but has not been optimal. The Navy as a military force is part of implementing the policy to realize the main program of Maritime Diplomacy, namely increasing the active role in efforts to create world peace and security. The Indonesian Navy describes the policy through the perspective of modern maritime defense policies that understand the nation's history to meet aspects of political will (maritime diplomacy). The Indonesian Navy with its limitations implements Maritime Diplomacy
Policy through cooperative, persuasive and coercive efforts.

There are six factors that influence the implementation of Maritime Diplomacy Policy in Papua, including: 1) Size and Policy Objectives; 2) Resources; 3) Characteristics of Implementing Agencies; 4) Communication between Implementing Agencies and Implementing Activities; 5) Disposition of Implementing Agencies; and 6) Environmental Effects. The last factor greatly influences the level of success of the Maritime Diplomacy Policy Implementation in the Land of Papua. Environmental influences can come from within and from outside. The main internal influence comes from the longstanding conflict in Papua. External influences take the form of conventional and non-conventional threats.

The implementation of maritime diplomacy in Papua should be carried out using two channels in parallel and in harmony, namely the main line from the Ministry of Foreign Affairs and the second line using the Navy so that it can create opinion internationally so that Indonesian diplomats are in a superior bargaining position.

Development priorities for infrastructure are important, but the capacity and capability building of human resources is the most important thing that is actually needed by the people of Papua. The Indonesian Navy can assist efforts to improve the capabilities of these human resources to reach remote and outermost areas in the Papua region.

\section{ACKNOWLEDGEMENT}

The authors greatly acknowledge the support from Hang Tuah University Surabaya Indonesia for providing the necessary resources to carry out this research work. The authors are also grateful to the anonymous reviewers and journal editorial board for their many insightful comments, which have significantly improved this article

\section{REFERENCES}

Abdul Wahab, Solichin (2008). Analisis Kebijakan : Dari Formulasi ke Implementasi Kebijakan Negara Edisi Kedua. Bumi Aksara. Jakarta.

Agustino, Leo (2008). Dasar-dasar Kebijakan Publik. CV. Alfabeta. Bandung.

Akib, Haedar (2008). Artikulasi Konsep Implementasi Kebijakan: Perspektif, Model dan Kriteria Pengukurannya, Jurnal Kebijakan Publik. Jakarta.

Audrey R. Kahin dan George McT. Kahin (1997). Subversi Sebagai Politik Luar Negeri; Menyingkap Keterlibatan CIA di Indonesia. Pustaka Utama Grafiti. Jakarta.

Berlianto dalam international.sindonews.com diakses pada tanggal 25 Desember 2019

Burchill, Scott (1996). Theories of International Relations. Macmillan Publishing Company. 
Cozens, Peter (2002). 12th Maritime Cooperation Working Group Meeting. CSCAP.

Dunn. (2013) Pengantar Analisa Kebijakan Publik, Edisi Kedua. Gadjah Mada University Press. Yogyakarta.

Edward III, George C. (1984). Public Policy Implementing. Jai Press Inc. London.

Fakultas IImu Pengetahuan Sosial dan IImu Politik. (2018). Buku Panduan Akademik dan Penulisan Tesis(Program Studi Magister Publik Tahun Akademik 2018/2019. Universitas Hang Tuah. Surabaya.

Gray, Colin S. (1988). The Geopolitics of Superpower. University of Kentucky. Kentucky.

Grindle, Merilee S. (1980). Politics and Policy Implementation in The Third World. Princenton University Press. New Jersey.

Hans J Morgenthau and Kenneth W. Thompson (1985). Politics Among Nations, The Struggle For Power and Peace, New York.

Hendrajit dalam theglobal-review.com diakses pada tanggal 25 Desember 2019

Human Rights Watch dalam hrw.org diakses pada tanggal 26 Desember 2019

Indiahono. (2009). Perbandingan Administrasi Publik. Gaya Media. Yogyakarta.

Islamy, Irfan. (2009). Prinsip- prinsip Perumusan Kebijaksanaan Negara. Bumi Aksara. Jakarta.

Juliartha, Edward (2009). Model Implementasi Kebijakan Publik. Jakarta.

Kusumaatmadja, Mohtar (1985). Bunga Hukum Laut, Kumpulan Karangan. Pusat Studi Wawasan Nusantara. Hukum dan Pembangunan, Bandung.

Kevin Liptak dalam cnn.com diakses pada tanggal 26 Desember 2019

Lemhanas (1994). Geografi Politik dengan Penglihatan dari Segi Indonesia. Buku 1, 2 dan 3. Jakarta.

Marsetio (2014). Sea Power Indonesia. Universitas Pertahanan. Jakarta.

Marsetio (2014). A World Class Navy: The New Paradigm. Mabesal. Jakarta.

Mazmanian, Daniel A and Paul A. Sabatier. (1983). Implementation and Public Policy. Scott Foresman and Company. USA.

Meire (2014). Maritime Diplomacy in the $21^{\mathrm{st}}$ Century. Routledge. London.

Miles,M.B, Huberman,A.M, dan Saldana,J. (2014). Qualitative Data Analysis, A Methods Sourcebook, Edition 3. Sage Publications. USA.
Nugraha dan Sudirman (2019). Maritime Diplomacy Sebagai Strategi Pembangunan Keamanan Maritim Indonesia. Universitas Pertahanan Indonesia. Jakarta.

Nugroho (2006). Kebijakan Publik Untuk NegaraNegara Berkembang. Elek Media Komputindo. Jakarta.

Palma, Marry Ann (2003). Legal and Political Responses to Maritime Security Challenge in The Strait of Malacca and Singapore. CANCAPS. Philippines.

Palma, Marry Ann (2009). The Philippines as an Archipelagic and Maritime Nation; Interest, Challenges and Perspectives. RSIS. Singapore.

Peraturan Presiden No 2 Tahun 2015 tentang RPJMN 2015-2019

Peraturan Presiden No 16 Tahun 2017 tentang Kebijakan Kelautan Indonesia

Petocz (1987). Conservation and Development in Irian Jaya.Grifisindo. Jakarta

Purwanto \& Sulistyastuti. (2012). Implementasi Kebijakan Publik. Gaya Media. Yogyakarta.

R. Viotti, Paul and Mark V. Kauppi (1999). International Relations Theory: Realism, Pluralism, Globalism, and Beyond. Allyn and Bacon. London.

Subarsono. (2015). Analisa Kebijakan Publik Konsep, Teori dan Aplikasi. Pustaka Pelajar. Yogyakarta.

Sugiyono (2014). Metode Penelitian Kuantitatif, Kualitatif dan kombinasi (mixed Methods). Alfabeta. Bandung.

Susteyorini (2019). Kebijakan Kelautan Indonesia dalam Perspektif UNCLOS 1982. Jakarta.

Tippe, Syarifudin (2013). Implementasi Kebijakan Bela Negara di Perbatasan: Studi Kasus di Provinsi Papua. Universitas Pertahanan Indonesia. Jakarta.

Wibawa, Samodra (2002). Evaluasi Kebijakan Publik. Raja Grafindo Persada. Jakarta.

Widodo, Joko (2010). Analisis Kebijakan Publik. Bayumedia. Malang.

Winarno, Budi (2002). Teori dan Proses Kebijakan Publik. Media Pressindo. Yogyakarta

Winarno, Budi. (2005). Teori dan Proses Kebijakan Publik (edisi revisi). Media Pressindo. Yogyakarta

Winarno, Budi (2008). Kebijakan Publik Teori dan Proses (edisi revisi). Media Pressindo. Yogyakarta.

Winarno, Budi (2012). Kebijakan Publik: Teori, Proses dan Studi Kasus. CAPS.Yogyakarta.

Wright, Quincy (1955). The Study of International Relation, Century Crofts. Appleton. 